\title{
咳反射における喉頭の役割
}

\author{
横山貴 康*, 本間裕*, 岩切裕昌* \\ 小林吉 史**, 野中 聡*, 海 野 徳二*
}

\section{The Functions of the Larynx during Coughing}

\author{
Takayasu Yokoyama, M.D., ${ }^{*}$ Yutaka Homma, M.D., ${ }^{*}$ Hiromasa Iwakiri, M.D., ${ }^{*}$ \\ Yoshifumi Kobayashi, M.D., ${ }^{* *}$ Satoshi Nonaka, M.D., ${ }^{*}$ and Tokuji Unno, M.D.* \\ *Department of Otolaryngology and ${ }^{*}$ Department of Physiology, \\ Asahikawa Medical College, Hokkaido
}

In this study, we tried to analyze the role of the larynx during coughing. To do this, the activities of the intrinsic laryngeal and major respiratory muscles and the changes in intratracheal pressure were recorded during coughing in both nontracheotomized and tracheotomized conditions.

Experiments were carried out using non-anesthetized decerebrate cats. EMGs were recorded by means of bipolar electrodes made from thin $(50 \mu \mathrm{m})$ stainless steel wires implanted into the diaphragm (DIA), the rectus abdominis muscle (RA), the thyroarytenoid muscle (TA) and the posterior cricoarytenoid muscle (PCA). The intratracheal pressure was recorded using a micro-tip catheter pressure transducer. To evoke coughing, a stainless steel wire was inserted through a pin-hole in the trachea, and mechanical stimuli were applied at the tracheobronchial mucosa.

The mechanical stimuli consistently evoked a series of coughs. During coughing in both the non-tracheotomized and tracheotomized conditions, the TA, PCA, DIA and RA muscles exhibited burst discharges with a fixed pattern and intratracheal pressure increased up to 80 $\mathrm{cmH}_{2} \mathrm{O}$. However, the onset of the discharge of the RA muscle during coughing in the tracheotomized condition was significantly earlier than that in the non-tracheotomized condition. These results suggest that the function of the larynx during coughing is not only to ensure the closure of the airway, but also to modulate the phases of the respiratory muscle activity.

Key words : 咳反射，除脳ネコ，呼吸筋活動，内喉頭筋活動，気管切開

\section{I . はじめに}

咳反射は気道内に過剩に産生された分泌物や

*旭川医科大学耳鼻咽喉科学講座，**同・生理学第 2 講座

別刷請求： $\bar{\top} 078$ 北海道旭川市西神楽4-5-3-11 旭川医科大学耳鼻咽喉科学講座 横山貴康

投稿受付：1993年 4 月30日
気道に侵入した異物を排除するための重要な防 御反射の一つである。咳反射は深い吸気に続く 爆発的な呼気を特徵とする ${ }^{1)}$ 。この反射が有効 に機能するためには，咳の呼出期に生ずる気流 速度が気道内の液体あるいは固体粒子を排除す るのに十分であることが必要である。このよう な気流速度を形成するうえで，気道の閉鎖機能 を持つ喉頭が不可欠な役割を演じていることは 容易に推測できる。 
本研究では，咳反射における喉頭の機能的役 割を解明するため, 咳反射時の内喉頭筋, 呼吸 筋の筋活動および気管内圧を気管切開前後で比 較, 解析した。実験には自発呼吸を営み, 咳な どの反射を維持する無麻酔除脳ネコを用い $た^{2,3)}$ 。

\section{II. 方 法}

実験には 7 頭の無麻酔除脳ネコ（2.8～3.8 $\mathrm{kg}$ )を用いた。GOF 麻酔下に両側総頸動脈を結 禁し頭蓋骨を一部除去し，上丘と下丘の間で脳 幹を外科的に切断した。手術後動物の頭部およ び第 $1 \sim 3$ 胸椎棘突起を脳定位固定装置 stereotaxic apparatusに固定し, 腹部はラバーハ ンモックにて支えた。

咳反射の誘発には気管分岐部の気管粘膜に加 えた機械的刺激を用いた。第 $3 \sim 4$ 気管軟骨間 に小孔を開け，ガイドカニューレ下に直径 150 $\mu \mathrm{m}$ の鋼線を気管分岐部まで挿入し，気管粘膜 を周波数約 $5 \mathrm{~Hz}$ にて振動刺激した4)。

筋活動は主要呼吸筋として吸気筋である横隔 膜（diaphragm：DIA）と呼気筋の腹直筋 (rectus abdominis：RA)，内喉頭筋として声門 閉鎖筋である甲状披裂筋（thyreoarytenoid muscle：TA）と声門開大筋である後輪状披裂 筋 (posterior cricoarytenoid muscle : PCA)
より記録した。それぞれの筋に一対のステンレ ス線（直径50 $\mu \mathrm{m}$, 電極間距離 $3 \mathrm{~mm}$ ) を埋め込 み, 筋活動を導出した5)。

気管内圧は直径 $3 \mathrm{~F}$ のカテーテル先端式半導 体圧トランスジューサ（Millar 社，SPC-300, 周波数特性： $35 \mathrm{kHz}$ 以下）を経口的に気管分 岐部上約 $10 \mathrm{~mm}$ に挿入し，記録した。

咳反射に伴う筋活動および気管内圧の変化 は, FM データレコーダー(TEAC 社, MR-30) に同時に記録し,気管切開前後で比較解析した。

\section{III. 結 果}

正常呼吸時および咳反射時に記録された内喉 頭筋, 呼吸筋の筋活動と気管内圧変化の代表例 を図 1 に示した。正常呼吸時（図 1,A）には, 声門閉鎖筋である甲状披裂筋 (TA) はほとんど 発射活動を示さず，開大筋である後輪状披裂筋 （PCA）は横隔膜とほぼ同じ位相で発射活動を 示した。横隔膜 (DIA) の活動は吸気相に対応し て増強し, 腹直筋 (RA) はほとんど発射活動を 示さなかった。

一方，咳反射時 (図 1，B)にはすべての筋は その活動を増強し，かつ特徵的な位相関係を示 した。甲状披裂筋 (TA) は横隔膜の活動休止時 点とほぼ一致してその活動を一過性に増強し た。後輪状披裂筋（PCA）は吸気相にほぼ同期

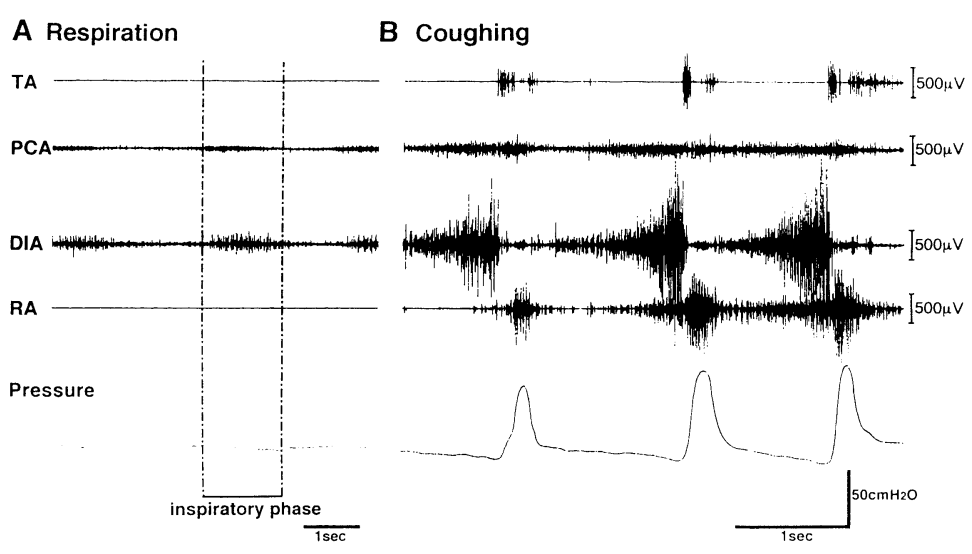

図 1 正常呼吸（A）抢よび咳反射時（B）における内喉頭筋・呼吸筋活動 と気管内圧の変化

$\mathrm{TA}$ ：甲状披裂筋, PCA：後輪状披裂筋, DIA：横隔膜, RA：腹直筋, Pressure : 気管内圧。 
して活動を増強し，一過性にその活動を減弱し た。さらに，気管内圧がほぼピークに達した時 点に再度，その活動を増強した。腹直筋（RA） は横隔膜活動が休止する時点にやや先行してそ の活動を増強し,気管内圧が上昇している期間, 活動増強を持続した。

気管内圧は横隔膜 (DIA) の活動が増強してい る期間徐々に低下し，甲状披裂筋 (TA) と腹直 筋 (RA) が同時に活動した時点に一致して急激 な上昇を示した。この圧の上昇は甲状披裂筋 （TA）の活動休止にやや遅れた時点まで持続 し, その後, 後輪状披裂筋（PCA）の活動とと もに急激に低下した。

\section{A Pre-Tracheotomy}
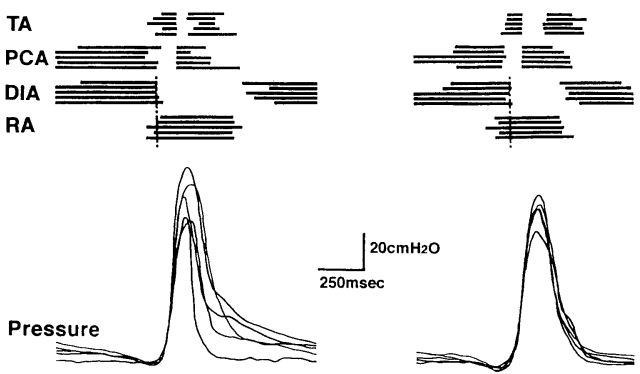

図 2 気管切開前 (A) および気管切開後（B）にお ける咳反射時の筋活動位相と気管内圧の変化 TA：甲状披裂筋, PCA：後輪状披裂筋, DIA：横隔 膜, RA：腹直筋, Pressure：気管内圧。
咳反射時の筋活動位相関係および気管内圧変 化を同一ネコで気管切開前後において比較し た。それぞれ 5 回の咳反射の結果を図 2 にまと めた。気管内圧の上昇開始時点を基準とし，筋 活動が著しく増強した期間をそれぞれ 1 本の横 実線で示し重ね合わせた。それぞれの筋活動に おいて，1番目から 5 番目までの実線は 1 回目 から 5 回目の咳反射に対応している。

気管切開前後ともに（図 $2, A ， B)$ ，腹直筋 （RA）の活動開始後に甲状披裂筋（TA）と後輪 状披裂筋（PCA）との活動交代が起こり，やや 遅れて気管内圧がピークに達した。気管内圧の ピーク值は気管切開前後で差は認めず，それぞ れ約 $80 \mathrm{cmH}_{2} \mathrm{O}$ であった。横隔膜 (DIA) と腹直 筋（RA）との筋活動交代の時点は明瞭でなく, 両者が同時に活動する期間が観察された。この 同時に活動する期間は，図中縦鎖線で示したよ うに,気管切開後に延長する傾向が認められた。

また，咳反射時の筋活動の強さを気管切開前 後にて比較した。そのため得られた筋電図を全 波整流後積分し，気管切開前の筋活動の振幅の 平均值を $100 \%$ とし比較した。その結果, 腹直筋 活動は気管切開前に比べ気管切開後は $177 \pm 61$ $\%$ と有意 $(P<0.05)$ に増強した。

気管切開前後における横隔膜 (DIA) と腹直筋 （RA）の同時活動期間に注目して解析を加えた (図 3 )。図 3，A に示したように，DIA の急激

\section{B}

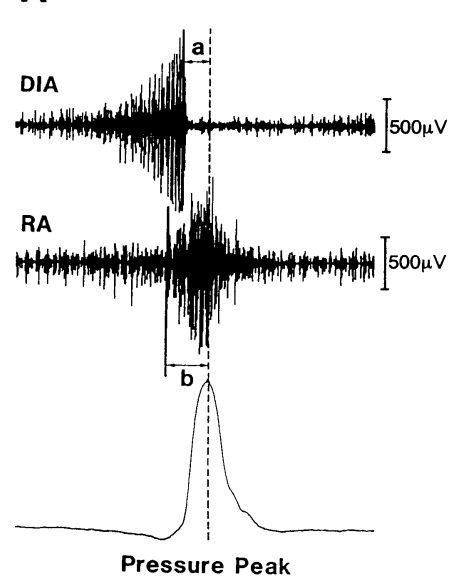

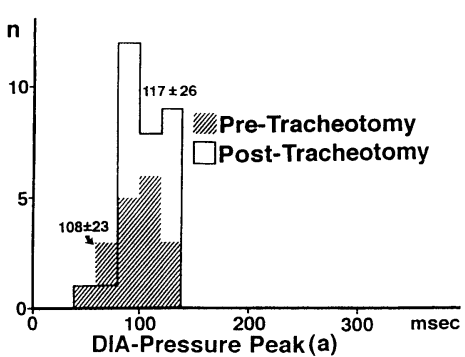

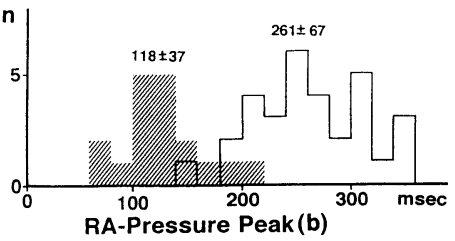

図 3 気管切開前後の横隔膜筋活動と腹直筋活動の位相関係 
な活動休止時点から気管内圧のピークまでの時 間を時間 $a, \mathrm{RA}$ の急激な活動増強開始時点か らピークまでの時間を時間 $b$ として, 同一ネコ の気管切開前後でそれぞれ比較した(図 $3, \mathrm{~B}$ )。

気管切開前の咳反射 $(n=18)$ から得られた值 を斜線, 気管切開後の咳反射 $(n=31)$ から得ら れた值を白抜きヒストグラムで示した。時間 $a$ は気管切開前で平均 $108 \pm 23 \mathrm{~ms}$, 切開後で平均 $117 \pm 26 \mathrm{~ms}$ であり, 有意な差は認められなかっ た。しかし, 時間 $b$ は気管切開前 $118 \pm 37 \mathrm{~ms}$ に 対し, 切開後には $261 \pm 67 \mathrm{~ms}$ と有意 $(P<0.01)$ に延長していた。気管切開前後で時間 $a$ が変化 しなかったことより, 横隔膜の活動休止時点が 気管内圧のピークに対して常に一定であること が明らかとなった。一方, 時間 $b$ が気管切開後 に延長したことは, 咳反射時の腹直筋の活動増 強が気管切開前と比べより早く開始することを 意味した。すなわち, 気管切開後には腹直筋が より早くその活動増強を開始するため, 横隔膜 との同時活動期間が延長すると考えられた。

\section{IV. 考 察}

従来より喉頭の機能は声門を強く閉じること を主体とする喉頭閉鎖機能, 声門を開いて気道 の一部とする呼吸機能, 適度に閉じて呼気流を 調節し音声を生成する発声機能に分類される。 喉頭閉鎖機能は気道防御機能とも考えられ，そ れゆえ咳反射は声門を閉鎖することによって成 立する閉鎖機能の一部としてとらえることがで きる6)。

咳反射時の声門開閉についての研究は過去に いくつかなされている7 9)。Tomori ${ }^{8,9)}$ は, 気管 内圧と声門開閉の関係を映画撮影法を用いて検 討した。その解析により, 咳反射時の声帯の動 きは次のように解明されている。すなわち，吸 気相に声門は開大し，一時的な声門閉鎖と同時 に起こる呼気筋の収縮により気管内圧が上昇す る。その後声門が開大することにより肺から空 気を呼出し, 気管内圧の急激な低下を引き起こ す。今回の実験では内喉頭筋, 呼吸筋活動と気 管内圧を記録し, 咳反射時における筋活動の位 相関係を気管内圧と対応させて検討した。

その結果, 気管内圧は横隔膜と後輪状披裂筋 が同時に活動を示している期間徐々に低下し，
甲状披裂筋と腹直筋が同時に活動した時点で急 激な上昇を示した。その後, 声門開大を示す後 輪状披裂筋の活動開始とともに圧は急激に低下 した。これらの結果は, Tomori による映画撮影 法を用いた成績と矛盾しないものであった。

臨床的に喉頭摘出術や気管切開術を受けた患 者は喀痰の喀出困難をしばしば引き起こす。こ のことは咳反射における喉頭の重要性を裏付け るものと考兄らる。本研究は咳反射における 喉頭の役割を解明することを目的とし，除脳ネ コに気管切開を加え, その前後で呼吸筋 - 内喉 頭筋活動および気管内圧の変化を比較した。

今回の解析より次のような知見を得ることが できた。

1 ) 峐反射時の最大気管内圧は気管切開前後 で変化なく,ともに約 $80 \mathrm{cmH}_{2} \mathrm{O}$ の圧上昇が観 察された。咳反射時の気管内圧上昇に要する時 間は約 $140 \mathrm{~ms}$ (周波数; 約 $7 \mathrm{~Hz}$ ) であり, 測定 に使用した半導体圧トランスジューサ（Millar 社, SPC-300)の周波数特性は $35 \mathrm{kHz}$ 以下であ ることから，ほぼ正確に咳反射時の気管内圧変 化を記録できたものと考えられた。咳反射時の 気管内圧が気管切開前後で変化しなかったこと より，喉頭の有無に関係なく，咳反射に必要な 気道内圧の上昇が引き起こされることが明らか となった。この結果は, 喉摘者と正常者の咳反 射時における食道内圧の比較で得られた成績 ${ }^{10)}$ と同様であった。

2 ) 横隔膜と腹直筋の同時活動期間が気管切 開後に延長し, 呼吸筋の位相が気管切開前と比 較し変化することが明らかとなった。すなわち， 腹直筋の筋活動増強が気管切開を施行すること により, 切開前に比べより先行して開始する。 また, 腹直筋活動の振幅は気管切開後に増強す ることが観察された。

有効な咳反射には気道内圧上昇後の強い呼気 流の形成が必要である。喉頭が存在する場合, 声門閉鎖と同時に呼気筋が収縮し気道内圧が上 昇する。その後, 声門は急激に開大し一気に気 流が呼出される。今回の実験で気管切開後には, 腹直筋活動は先行増強し, 拮抗筋である横隔膜 との同時活動期間が延長した。このことは, 横 隔膜活動の休止時点においてすでに腹直筋は強 く収縮し, 気流を一気に呼出する準備ができて 
いることを示唆した。

ヒトにおいて腕を屈曲した状態で重い荷物を 持つ場合，拮抗筋が同時に収縮することが知ら れている ${ }^{11)}$ ここのことは, 主動筋と拮抗筋が同時 に収縮することにより主動筋の強い収縮が可能 になることを推測させる。主動筋と拮抗筋が同 時に収縮し，その後の拮抗筋弛緩によって主動 筋の急激な運動が生じることは動物を用いた実 験で明らかにされている12)。

気管切開後の咳反射時には，吸気筋と呼気筋 が同時に活動することで呼気筋活動が増強し, 急激な気管内圧上昇を形成したと考えられる。 さらに，気管切開により咳反射時の呼吸筋活動 の位相に変化が現れたことは，喉頭が咳反射時 に単純に気道を閉鎖するばかりでなく，反射時 の種々の活動筋群の位相調節にも重要な役割を 果たしていることを示唆した。

\section{V.まと め}

咳反射時の呼吸筋活動・気管内圧を気管切開 前後において比較検討した。喉頭は咳反射の形 成に重要な役割を果たし，とくに呼吸筋活動の 位相関係に影響を及ぼすことが明らかとなっ た。

本論文の一部は第44回日本気管食道科学会総会 （1992年，東京）において発表した。

\section{文献}

1) 加瀬佳年：咳の薬理. 呼と循，11：425-435, 1963.

2 ) Grelot, L., and Milano, S. : Diaphragmatic and abdominal muscle activity during coughing in the decerebrate cat. Neuroreport, 2 : 165-168, 1991.

3 ) Bolser, D.C. : Fictive cough in the cat. J. Appl. Physiol., 71 : 2325-2331, 1991.

4 ) Korpas, J., and Tomori, Z. : Cough and other respiratory reflexes. Progress in Respiration Research, Vol. 12, pp.15-188, Karger, Basel, 1979.

5 ）野中 聡，太田善博：〈しゃみの神経機構と 呼・吸気ニューロン活動。日耳鼻, $88 ： 760-770$, 1985.

6 ）廣瀬 肇：喉頭の機能. 日気食会報，38： 334-335, 1987.

7 ) Farnsworth, D.W. : High-speed motion pictures of the human vocal cords. Bell Laboratories Record, 18 : 203-208, 1940.

8 ) Tomori, Z. : The function of the glottis in respiratory tract reflexes. Folia Med. Martiniana, $4: 243-258,1979$.

9 ) Tomori, Z. : The changes in transpulmonary and transglottal pressures in respiratory tract reflexes. Folia Med. Martiniana, 4 : 259-269, 1979.

10）海野徳二：喉摘者の咳。日気食会報, $26 ： 15-22$, 1975.

11）島村宗夫：骨格筋の神経支配と運動反射. 生理 学体系 Vl, pp. 391-424, 医学書院, 東京, 1973.

12）岡島 昭, 丸山工作 : 行動の生理学. 運動と行 動，pp. 1-56，岩波書店，東京， 1975 . 